\section{Seriously, Should We Be Treating Severe ARDS With High-Flow Nasal Cannula Oxygen?}

\section{To the Editor:}

We have read with interest the RESPIRATORY CARE article entitled "Use of high-flow nasal cannula oxygen therapy in subjects with ARDS: a 1-year observational study". ${ }^{1}$ We are surprised that, compared with an overall mortality of $29 \%$, the mortality in the group treated with high-flow nasal cannula (HFNC) oxygen therapy and subsequently needing intubation was $50 \%$. This is close to the value determined by Antonelli et $\mathrm{al}^{2}$ in 2007: $56 \%$ mortality in subjects treated with noninvasive ventilation (NIV) and finally intubated due to NIV failure. Because there was a possible delay in the intubation of these subjects the result was a higher mortality rate. In addition, mortality could have been prevented if, instead of being treated with NIV, patients with ARDS were initially intubated and treated with the open-lung strategy with high PEEP. ${ }^{3}$

The current mortality due to ARDS varies between 20 and $60 \%$ depending on many factors, but there is a clear relationship that has been established between the level of PEEP, the $\mathrm{P}_{\mathrm{aO}_{2}} / \mathrm{F}_{\mathrm{IO}_{2}}$ that is reached with this PEEP, and mortality. ${ }^{4}$ Thus, in patients intubated and ventilated with a PEEP of $>10 \mathrm{~cm} \mathrm{H} \mathrm{H}_{2} \mathrm{O}$, if the $\mathrm{P}_{\mathrm{aO}_{2}} / \mathrm{F}_{\mathrm{IO}_{2}}$ is $<150$, the mortality rate is $60.3 \%$, which is very similar to the rate found by Antonelli et $\mathrm{al}^{2}$ in subjects with delayed intubation.

In ARDS, the ventilation strategy is aimed at reducing the intrapulmonary shunt with the use of continuous distending pressure. Due to the high rate of associated failure and secondary mortality, there are some physicians who advise against the continuation of NIV in patients with ARDS if, after $1 \mathrm{~h}$ of treatment, oxygenation has not improved to a $\mathrm{P}_{\mathrm{aO}_{2}} / \mathrm{F}_{\mathrm{IO}_{2}}$ of $>175^{2}$ (the intrapulmonary shunt when $\mathrm{P}_{\mathrm{aO}_{2}} / \mathrm{F}_{\mathrm{IO}_{2}}>175$ is $\sim 35 \% 5$ ). In recent clinical trials involving hypoxemic respiratory failure in the pediatric population, HFNC was not shown to have better results than standard low-flow oxygen therapy, ${ }^{6}$ and both therapies had a higher mortality rate than CPAP therapy. ${ }^{7}$

In mild hypoxemic situations, although NIV produces better oxygenation, HFNC is subjectively better tolerated, and it can be considered as a reasonable alternative ther- apy. ${ }^{8}$ However, we disagree with the use of HFNC in moderate or severe ARDS $\left(\mathrm{P}_{\mathrm{aO}_{2}} /\right.$ $\mathrm{F}_{\mathrm{IO}_{2}}$ of $<200$ ). ARDS is a clinical condition with high mortality. If the decision to use NIV is made, it should be started with CPAP or bi-level positive airway pressure. However, if an improvement in oxygenation $\left(\mathrm{P}_{\mathrm{aO}_{2}} / \mathrm{F}_{\mathrm{IO}_{2}}\right.$ of $\left.>175\right)$ is not obtained after $1 \mathrm{~h}$ of NIV, the patient should be intubated to improve the level of recruitment and to minimize the intrapulmonary shunt.

So the question now is, are we sure that using HFNC initially, instead of conventional mechanical ventilation in patients with severe ARDS, does not increase mortality? In our opinion, the answer is no. If, as patients, we happened to have severe ARDS, we would definitely choose conventional mechanical ventilation from the very beginning.

Alberto Medina MD PhD

Pediatric Intensive Care Unit Department of Pediatrics

Hospital Universitario Central de Asturias Oviedo, Asturias, Spain

Vicent Modesto i Alapont MD PhD Pediatric Intensive Care Unit Department of Pediatrics

Hospital Universitari i Politècnic La Fe València, Valencia, Spain

The authors have disclosed no conflicts of interest.

DOI: $10.4187 /$ respcare. 04147

\section{REFERENCES}

1. Messika J, Ben Ahmed K, Gaudry S, Miguel-Montanes R, Rafat C, Sztrymf B, et al. Use of high-flow nasal cannula oxygen therapy in subjects with ARDS: a 1-year observational study. Respir Care 2015; 60(2):162-169.

2. Antonelli M, Conti G, Esquinas A, Montini L, Maggiore SM, Bello G, et al. A multiple-center survey on the use in clinical practice of noninvasive ventilation as a firstline intervention for acute respiratory distress syndrome. Crit Care Med 2007; 35(1):18-25.

3. Amato MB, Barbas CS, Medeiros DM, Magaldi RB, Schettino GP, Lorenzi-Filho $\mathrm{G}$, et al. Effect of a protective-ventilation strategy on mortality in the acute respiratory distress syndrome. N Engl J Med 1998; 338(6):347-354

4. Villar J, Fernández RL, Ambrós A, Parra L, Blanco J, Domínguez-Berrot AM, et al. A clinical classification of the acute respiratory distress syndrome for predicting out- come and guiding medical therapy. Crit Care Med 2015;43(2):346-353.

5. Reske AW, Costa EL, Reske AP, Rau A, Borges JB, Beraldo MA, et al. Bedside estimation of nonaerated lung tissue using blood gas analysis. Crit Care Med 2013; 41(3):732-743

6. Hathorn C, Ernst G, Hasan S, Wong D, Seear M. The Hi-flo study: a prospective open randomised controlled trial of high flow nasal cannula oxygen therapy against standard care in bronchiolitis (abstract) Thorax 2014;69:A38.

7. Chisti MJ. Respiratory support for children with severe pneumonia and hypoxaemia in a developing country: a randomized trial of bubble CPAP, high flow nasal cannula therapy and standard flow oxygen. $\mathrm{PhD}$ thesis, 2014. http://hdl.handle.net/11343/42117. Accessed May 5, 2014.

8. Schwabbauer N, Berg B, Blumenstock G, Haap M, Hetzel J, Riessen R. Nasal highflow oxygen therapy in patients with hypoxic respiratory failure: effect on functional and subjective respiratory parameters compared to conventional oxygen therapy and non-invasive ventilation (NIV). BMC Anesthesiol 2014;14:66

\section{Seriously, Should We Be Treating Severe ARDS With High-Flow Nasal Cannula Oxygen?-Reply}

In Reply:

We thank Drs Medina-Villanueva and Modesto i Alapont for their interest in our work. ${ }^{1}$ They question the use of high-flow nasal cannula (HFNC) oxygen for the management of ARDS. The crucial point missed by Drs Medina-Villanueva and Modesto i Alapont is the basic philosophy of acute respiratory failure management.

We know that not all patients who are ultimately diagnosed with ARDS immediately fulfill all ARDS criteria. In addition, not all patients with ARDS arrive already intubated in the ICU, and not all of them present with immediate intubation criteria. This means that a significant proportion of patients arrive in the ICU with severe acute respiratory failure, still breathing spontaneously, usually with supplemental oxygen administered via a face mask. Hence, until recently, clinicians could choose from 3 options: immediately intubate (even in the absence of intubation criteria as suggested by Drs MedinaVillanueva and Modesto i Alapont), initiate noninvasive ventilation (NIV), or continue conventional oxygenation. 